\title{
STATUS DAN KEDUDUKAN ANAK LAKI-LAKI CACAT FISIK MENURUT HUKUM ADAT BALI DI DESA PAKRAMAN TABOLA KECAMATAN SIDEMEN, KABUPATEN KARANGASEM
}

\author{
Oleh \\ I Nyoman Putra Adnyana
}

\begin{abstract}
ABSTRAK
Berdasarkan kajian yang telah dilakukan, diperoleh hasil bahwa Pembagian waris di Desa Pakraman Tabola serta anak-lali-laki cacat fisik tidak mendapat warisan namun tidak multak akan tetapi bisa digantikan oleh keluarga golongan ahli waris ke tiga. Waris telah diatur dalam awig-awig Desa Pakraman Tabola. Seorang ahli waris harus memiliki kemampuan dan pengetahuan secara jasmani dan rohani sehingga apa yang menjadi tanggungjawab yang diberikan kepadanya dapat dijalankan sesuai dengan pemberi waris untuk kelangsungan kehidupan yang akan datang baik sekala dan niskala seperti gotong royong, ngayah, serta upacara keagamaan di sanggah/merajan serta di Pura Kahyangan Tiga.
\end{abstract}

\section{PENDAHULUAN}

Seperti nampak dari beragamnya sistem kekeluargaan yang dianut dalam masyarakat Indonesia dengan tidak adanya hukum waris yang berlaku secara nasional maka hukum waris yang berlaku bagi masyarakat Bali adalah Hukum Waris Adat Bali. Melihat dari hal itu masyarakat Bali terikat oleh norma-norma hukum yang mengatur pergaulan hidup mereka, baik yang berupa hukum tertulis maupun yang berupa hukum tidak tertulis. Hukum yang tertulis yang berlaku berasal dari negara dalam bentuk peraturan perundang-undangan republik Indonesia, sedangkan hukum yang tidak tertulis yang berlaku bersumber dari kebiasaan-kebiasaan masyarakat yang di sebut Dresta, karena kondisi sosial budaya setiap suku Bangsa mempunyai kekhasan masing-masing menyebabkan tidak mungkin semuanya dapat diatur secara nasional.
Tercatat sampai hari ini bidangbidang hukum dan waris di bali belum dapat diatur secara nasional. Sehingga pada bidang-bidang kehidupan itu sering tetap berlaku Hukum Adat Bali. Dan di dalam hal ini perlu dijelaskan apa itu Hukum Adat Bali yaitu adalah kompleks norma-norma, baik dalam wujudnya yang tertulis maupun tidak tertulis, berisi perintah, kebolehan dan larangan, yang mengatur kehidupan masyarakat Bali yang menyangkut hubungan antara sesama manusia, hubungan antara manusia dengan lingkungan alamnya, dan hubungan manusia dengan tuhanya. Tujuan hukum adalah tujuan hidup itu sendiri yaitu terciptanya kesejahtraan umat manusia yang di terjemahkan sebagai kehidupan 'sukerta sakala niskala' dalam konsep orang Bali.

Menyinggung Hukum Adat dalam kewarisan kita sistem hukum kita yang sekarang ini masih mendasarkan kepada pegangan sistem kekeluargaan 
yang di anut oleh masing masing suku di Indonesia ini. Masalah waris di akui oleh beberapa pihak sebagai salah satu bagian dari Hukum Adat Bali yang paling sukar, karena adanya kebiasaankebiasaan yang berbeda dalam masyarakat Bali, seperti masalah hukum waris yang ada di Desa Pakraman Tabola Kecamatan Sidemen Kabupaten Karangasem tentang hak waris anak laki-laki cacat fisik seperti tuna netra, tuna rungu dan tuna daksa karena di desa Pakraman Tabola

Memiliki kebiasaan-kebiasaan yang berbeda itu terdapat asas-asas yang universal yang berlaku bagi orang Bali Secara umum, pembahasaan mengenai Hukum Adat Waris tidak lepas dari tiga kata kunci yang menjadi unsur unsur pewarisan yaitu pewaris, harta warisan, dan ahli waris, dalam aspek-aspek inilah akan dilihat asasasas Hukum Adat Waris yang berlaku bagi semua orang-orang Bali. Di dalam hukum waris Bali yang berhak mewarisi adalah dari bapaknya atau dari garis keturunan si laki-laki pewaris adalah orang yang akan memberikan warisanya kepada anaknya atau kepada ahli warisnya (Windia, 2006:115)

Kemudian warisan adalah sesuatu yang di wariskan baik berupa harta, nama baik dan lain lain, dalam Hukum Adat Bali warisan tidak hanya berupa harta benda tetapi juga berupa hak hak kemasyarakatan.dan ahli waris adalah orang yang nantinya akan menerima warisan. Pewarisan dalam Hukum Adat Bali tidak semata mata berisi hak ahli waris atas harta warisanya. Lebih dari itu yang terpenting adalah kewajiban ahli waris terhadap pewaris. Sebagai konsekuensi dari hak yang di terima, seorang ahli waris mempunyai kewajiban-kewajiban tertentu yaitu.
1) Memelihara pewaris ketika pewaris dalam keadaan tidak mampu

2) Menguburkan jenazah pewaris dan atau menyelenggarakan Pengabenan (upacara pembakaran jenazah) bagi pewaris dan menyemayamkan arwahnya di Sanggah atau Merajan (tempat persembahyangan keluarga)

3) Menyembah leluhur yang bersemayam di Sanggah atau Merajan

4) Melaksanakan kewajiban-kewajiban (ayahan) terhadap Banjar atau Desa

Kelalaian terhadap kewajibankewajiban di atas dapat di jadikan alasan untuk memecat kedudukan seseorang sebagai ahli waris yang artinya terputus haknya untuk menerima warisan. Bagaimana jika masalahnya ahli warisnya anak laki laki cacat fisik seperti halnya di Desa Pakraman Tabola Kecamatan Sidemen, apakah warisanya akan di terima atau di serahkan ke drue tengah atau merajannya. Dalam keluarga Bali, keturunan laki-lakilah yang berfungsi sebagai pelanjut keturunan atau istilahnya Sentana. Berdasarkan permasalahan di atas, maka penulis tertarik untuk melakukan penelitian mengenai hak waris anak laki-laki cacat fisik di Desa Pakraman Tabola Kecamatan Sidemen.

\section{PEMBAHASAN}

\subsection{Status Anak laki-laki Cacat Fisik dalam Waris menurut Hukum Adat Bali di Desa Adat Tabola}

Dalam Hukum Adat anak-anak dari si peninggal warisan merupakan golongan ahli waris yang terpenting oleh karena mereka pada hakekatnya merupakan satu-satunya golongan ahli waris sebab lain-lain anggota keluarga tidak menjadi ahli waris apabila si 
meninggal warisan meninggalkan anakanak. Jadi dengan meninggalkan anakanak kemungkinan lain-lain anggota keluarga dari si peninggal warisan untuk menjadi ahli waris menjadi tertutup sedangkan tentang pembagianya menurut keputusan Mahkamah Agung tanggal 1 November 1961 Reg. No. 179/K/Sip/1961, anak perempuan dan anak laki-laki dari seorang peninggal warisan bersama hak atas harta warisan dalam arti bahwa bagian anak laki-laki adalah sama dengan perempuan (Lestawi, 1999 : 58)

Dalam pandangan tradisional yang masih kuat mendominasi alam pikiran masyarakat Bali, pewaris adalah seorang ayah (laki-laki). Paham ini nampaknya dilandasi pemikiran bahwa dalam sistem kekeluargaan purusa yang patriarkhi ayah adalah kepala kelurga, pencari nafkah dan pemilik harta keluarga yang diwarisinya secara turun temurun dari ayah ayah sebelumnya dalam logika ini, harta warisan di turunkan melalui garis laki-laki sehingga semua harta adalah milik lakilaki sedangkan perempuan bukanlah pemilik harta. Mengenai ahli waris dalam Hukum Adat dikenal adanya penggolongan ahli waris berdasarkan garis pokok keutamaan yaitu adalah garis hukum yang menentukan urutanurutan keutamaan diantara golongangolongan keluarga pewaris dengan pengertian bahwa golongan yang satu lebih diutamakan dari golongan yang lain.

Wawancara dengan I Gusti Ngurah Mantra Spd, Jero Bendesa Desa Pakraman Tabola mengatakan bahwa mengatatakan bahwa hak mewaris anak laki-kaki menurut Hukum Adat Bali merupakan hak tertinggi karena merupakan tanggung jawab Sekala dan Niskala, Skala tanggung jawab merawat seseorang yang memberikan warisan baik orang laki dan perempuan yang masih hidup, dan niskala tanggung jawab melakukan Yadnya seperti Piodalan di Sanggah atau merajan keluarga serta ngayah di Desa Pakraman.

Dalam Hukum Adat Bali yang berdasarkan pada sistem kekeluargaan kepurusa, orang-orang yang dapat diperhitungkan sebagai ahli waris dalam garis pokok keutamaan dan dakam garis pokok pengganti adalah para laki-laki dalam keluarga yang bersangkutan sepanjang tidak terputus haknya sebagai ahli waris. Kelompok orang orang yang termasuk dalam garis keutamaan pertama sebagai ahli waris adalah keturunan pewaris lurus atau kencang ke bawah yaitu anak kandung laki-laki (Windia dan Sudantra, $2006: 120$ ).

Di dalam hal Hukum Adat Bali kusunya tentang waris karena sistem kekeluargaan Purusa atau garis laki-laki jadi yang paling berhak menjadi ahli waris selanjutnya adalah anak laki-laki yang sudah cukup dewasa yang sudah bisa menjalankan hak dan kewajibanya sebagai ahli waris. Proses penerusan harta warisan sudah dimulai saat pewaris masih hidup terutama terhadap warisan yang dapat di bagi bagi apabila ahli waris lebih dari satu orang. Hal itu dapat dilakukan dengan pemberian harta yang bersifat sementara misalnya pengupajiwa yaitu untuk nafkah si ahli waris.

Ketika anak laki-laki yang pertama berumah tangga dan mandiri maka ia akan melanjutkan hak dan kewajiban pewaris yaitu seperti menyembah arwah leluhur yang bersemayam di Sanggah/pemerajan kemudian melaksanakan kewajiban kewajiban ayahan terhadap Banjar atau 
Desa ini si ahli waris anak laki-laki sehat secara rohani dan jasmani namun jika anak laki-laki cacat fisik yang tidak bisa melaksanakan kewajibankewajibanya dalam ayahan terhadap Banjar. Tetapi Proses penerusan harta warisan sudah dimulai saat pewaris masih hidup terutama terhadap warisan yang dapat di bagi-bagi karena masih adanya si pewaris Hal itu dapat dilakukan dengan pemberian harta yang bersifat sementara misalnya Pengupajiwa yaitu untuk nafkah si ahli waris.

Keadaan cacat fisik disini si ahli waris tetap sebagai ahli waris namun di bawah pengampuan si pewaris dan hanya dapat menikmati harta dari si pewaris untuk sementara karena si ahli waris tidak bisa melaksanakan kewajiban-kewajiban sebagaimana mestinya. Dan Karena ahli waris golongan pertama tidak ada atau tidak bisa melaksanakan kewajiban kewajibanya karena cacat maka yang berhak atas harta warisan adalah golongan ahli waris ke dua yaitu orang tua pewaris jika masih ada. Jika tidak barulah diperhitungkan saudara saudara pewaris ke tiga yaitu saudara saudara atau sepupu pewaris atau keturunanya sebagai ahli waris pengganti.

Berdasarkan hal tersebut pewarisan bisa terlaksana disaat setelah si pewaris diaben namun karena dalam hukum waris adat Bali melihat kondisi anak laki-laki cacat fisik disini hak waris tetap mendapat hak waris yang dapat dibagi bagi yaitu untuk menghidupi kehidupanya sehari hari tetapi karena anak laki-laki cacat fisik tidak bisa melaksanakan hak dan kewajibanya sebagi warga dalam Desa Adat maka proses pewarisan ini dengan cara mengganti sesuai dengan pasal 841 pergantian pewaris, penggantian dalam garis lurus kebawah yang sah berlangsung terus dan tiada akhirnya untuk bertindak sebagai pengganti dalam derajat dan dalam hak orang yang diganti.

\subsection{Kedudukan Waris anak laki-laki cacat fisik menurut Hukum Adat Bali di Desa Adat Tabola}

Di dalam hukum Waris Adat Bali yang menggunakan sistem kekeluargaan patrilineal atau garis kepurusa. Patrilineal adalah suatu Adat masyarakat yang mengatur alur keturunan berasal daripihak ayah. Dimana jika terjadi masalah maka yang bertanggung jawab adalah pihak lakilaki. Selain di Bali Sistem kekeluargaan ini dianut oleh Bangsa Arab, Eropa, dan suku Batak yang hidup di daerah Sumatra Utara.

Kata patrilineal sering kali disamakan dengan patriakhat atau patriarkhi, meskipun pada dasarnya artrinya berbeda patrilineal berasal dari dua kata yaitu "pater" berarti ayah dalam bahasa latin dan "linea" yang berarti garis jadi patrilineal berarti mengikuti garis keturunan yang ditarik dari pihak ayah. Sehingga keturunan laki laki yang berhak mewarisi harta peninggalan pewaris yang meninggal dunia, sedangkan anak perempuan sama sekali tidak mewarisi

Menurut awig-awig Desa Pakraman Tabola dijelaskan bahwa yang berhak mewaris adalah orang orang atau lakilaki yang bisa memenuhi persyaratan sesuai awig-awig Desa Pakraman Tabola Palet 5, Pawos 46

Berbunyi:

1. .Luwire sane wenang kawarisin : 
ha Hamong amongan ring Desa, ayahayahan sahurah arih na. Hutang, pihutang sang kawarisinca. Saraja druwe, brana, tegal, carik, tatamiyan, sakancan kasugihan

2. Sane wenang Ngawarisin :

ha. Manut lalaintih paparenahan adoh tampek saking purusa tinggal sidhikara, tunggal dadya.

na. Putra dadaman wiyadin putra paparasan

ca. Sentana saking Nuduk mantu

ka. Sangkaning polih pitemes saking sang kawarisin sang madruwe salwir sane daos kawarisang kasaksisinin antuk Guru Wisesa, pinih akeh apahtigaan saking padruwen nane.

3. Sang sapusira hugi Krama Desa Pakraman Tabola, tilar saking Agama Hindu tan Yogya ngawaris sane kamulan patut kawarisin

4. Ngedum wawarisan kepatut sesampun puput maabenang sang ngawarisang brana punika. Sane dados dum, sajaba sane maangge padagingan angaci aci, minakadi salwiring sane maange piranti nglaksanayang upacara Agama.

Menurut awig-awig Desa Pakraman Tabola yang berhak mewaris menurut hukum atau awig-awig yang di Desa Pakaraman Tabola adalah orang atau anak laki-laki yang mampu melaksanakan kewajiban-kewajiban diatas, dengan kata lain harus si yang mewarisi harus sehat lahir dan batin, yang dalam hal ini bahwa anak laki-laki cacat fisik tidak bisa mewaris karena tidak mampu melaksanakan kewajibankewajiban yang harus ia warisi dari si pewaris namun dalam hal ini proses pewarisan sudah dimulai ketika pewaris masih hidup terutama harta warisan yang dapat dibagi-bagi secara individual apalagi ahli waris lebih dari satu orang semasih hidup pewaris pada umumnya sudah membagikan hartanya kepada ahli warisnya dengan tujuan untuk menghindari kesulitan-kesulitan di kemudian hari apalagi jika si pewaris memiliki anak laki-laki cacat fisik yang barang tentu tidak bisa melaksanakan hak dan kewajibanya seperti bekerja dan mengurus orang tuanya atau si pewaris. Pemberian harta benda ini di sebut pengupajiwa. Di dalam hal ini karena kondisi anak laki laki cacat fisik tidak bisa melaksakan kewajibanya maka yang memiliki hak atas harta warisan adalah golongan ahli waris keutamaan ke dua yaitu orang tuanya namun jika sudah meninggal maka yang berhak adalah dari garis golongan ketiga yaitu saudara pewaris sebagi ahli waris pengganti yang nantinya akan melaksanakan kewajiban kewajibanya di masyarakat atau di Desa

\section{PENUTUP}

Berdasarkan penjabaran dari hasil penelitian yang telah dilakukan, sebagaimana diuraikan di atas, dapat ditarik simpulan sebagai berikut:

1. Dalam hal waris menyangkut anak laki-laki menurut Hukum Adat Bali merupakan hak tertinggi karena merupakan tanggung jawab sekala dan niskala, skala tanggung jawab merawat seseorang yang memeberikan warisan baik orang laki dan perempuan yang masih hidup, dan niskala tanggung jawab melakukan yadnya seperti piodalan di Sanggah atau Merajan keluarga serta ngayah di Desa pakraman.

2. Dalam Hukum Adat Bali menggunakan sistem 
kekeluargaan patrilineal atau garis kepurusa. Maka yang berhak mewaris adalah mengikuti garis bapak atau laki laki, dan menurut Hukum Adat Bali yang berlaku di Desa Pakraman Tabola anak laki-laki yang berhak mewaris adalah yang sehat jasmani dan rohani, berarti di dalam hal ini anak laki-laki cacat fisik tidak mendapatkan hak secara mutlak karena di sini berlaku ahli waris pengganti dengan catatan ahli waris pengganti.

\section{DAFTAR PUSTAKA}

Windia, W. P. dan Sudantra I K. 2006. Pengantar Hukum Adat Bali. Lembaga Dokumentasi dan Publikasi Fakultas Hukum Universitas Udayana.

Windia, W. P. 2008. Tanya Jawab Hukum Adat Bali. Majelis Utama Desa Pakraman Provinsi Bali.

Pudja, G. 1997. Hukum Kewarisan Hindu Yang Direfisir Ke Dalam Hukum Adat Bali Dan Lombok. Jakarta: Penerbit CV Junesco.

Rini, S. 2009. Kedudukan Anak Angkat Dalam Pewarisan Menurut Hukum Adat Bali

Sandidevi, I.A. 2012. Kedudukan Anak Perempuan Dalam Sistem Waris Adat Bali 